\title{
The Relationship Between the Teaching Goal Orientations and Teaching Approach of Physical Education and Sports Teachers
}

\author{
Veysel Sarıül \\ The Elazig İşitme Engelliler School, The Ministry of National Education \\ Abdullah Paşa, 254. Street, 23270, Elazig, Turkey \\ Tel: 90-505-631-00-66 E-mail: vyslsrg179@gmail.com \\ Yunus Emre Karakaya \\ Faculty of Sport Sciences, Firat University \\ 23119 Elazig, Turkey \\ Tel: 90-505-631-00-66 E-mail: emrekarakaya@firat.edu.tr
}

Uğur İnce (Corresponding author)

School of Physical Education and Sports, Harran University

Osmanbey Campus, 63300, Sanliurfa, Turkey

Tel: 90-541-291-96-23 E-mail: ugurince@harran.edu.tr

\section{Cemal Yalçın}

The Şehit Onder Pinar Secondary School, The Ministry of National Education Abdullah Paşa, 254. Street, 23270, Elazig, Turkey

Tel: 90-531-626-08-25Ｅ-mail: cemmalyalcin@hotmail.com

Received: March 7, $2021 \quad$ Accepted: April 10, $2021 \quad$ Published: April 23, 2021

doi:10.5296/jei.v7i1.18384 URL: https://doi.org/10.5296/jei.v7i1.18384 


\section{Abstract}

This study was conducted in line with the opinions of physical education and sports teachers working in educational institutions to reveal the relationship between goal orientation towards teaching and teaching approaches. A total of 279 physical education and sports teachers from different schools in Elazig were enrolled in the study. To determine the target orientation of the research group towards teaching 'Goal Orientation Scale for Teaching' and to determine the teaching approaches 'Instructional Approaches Inventory' were used. The data obtained are saved by using the licensed SPSS 22.0 package program. 'One Way Analysis of Variance (ANOVA)' and 'Pearson Correlation Analysis' has been made. As a result of the correlation analysis, a positive and high-level relationship between 'Goal Orientation Scale for Teaching' and 'Skill Approach' has been found ( $r=0.789 ; \mathrm{p}=0.000)$. It has been concluded that there was a very high positive correlation between the 'Teaching Approaches Inventory Scale' and 'Developmental' subscale $(r=0.932 ; p=0.000)$. The relationship between goal orientations towards teaching and teaching approaches was found to be positive and moderate $(\mathrm{r}=0.616 ; \mathrm{p}=0.000)$. The fact that physical education and sports teachers enrich their teaching by establishing a relationship between their goal orientations and teaching approaches towards teaching in the lesson process will further contribute to students' learning physical education and sports lessons in a meaningful way.

Keywords: Physical education, Sport, Teachers, Goal orientation, Teaching approach

\section{Introduction}

Qualified teachers are needed for a quality education process. The most important tasks of teachers are to facilitate learning, to be a role model and guide the students (Açıkgöz, 2003). Teachers' personality, instructive aspect, attitudes, behaviors and values significantly affect the student (Saraçoğlu, Karasakal, \& Evin-Gencel, 2010). In the training of qualified individuals, first of all, teachers should be aware of their qualifications and competencies (Dursun \& Dede, 2004; Dursun \& Peker, 2003).

Today, teaching has turned into a dimension of guiding students to increase their performance, rather than transferring knowledge. If the learning-teaching process is not happening as planned, the teacher should review this process and move on to new practices evaluated the goal orientation of teachers in the teaching process under four factors (Aydede et al., 2006; Butler, 2007): Mastery goal-oriented teachers aim to learn, develop and acquire professional skills; skill approach goal-oriented teachers aim to show their superior teaching skills; gaining skills goal-oriented teachers aim to avoid showing low-level teaching skills and avoiding work goal-oriented teachers aim to conclude the day with little effort. In many studies, it has been revealed that these goal orientations of teachers directly affect their teaching activities as well as students' learning and motivation (Butler \& Shibaz, 2014; Dresel et al., 2013; Butler \& Shibaz, 2008; Kucsera et al., 2011). For instance, in the classroom environments created by mastery goal-oriented teachers, processes such as providing personal opportunities for meaningful learning and self-development of students, and awareness of their efforts and developments are at the forefront. In the educational settings of performance goal-oriented teachers, there is an atmosphere where correct answers 
are prioritized, individual or group competitions are organized, comparisons such as showing good students as an example to other students in the classroom, and high achieving students are rewarded (Anderman et al., 2001; Dresel et al., 2013).

Explains the features that should be in teachers' goals as follows (Demirel, 2012):

Being convenient to the needs of students;

Being achievable;

Being student oriented, not teacher oriented;

Being limited to only one learning product;

Being chosen according to the level of education;

Being linked to the learning content;

Being in line with the logical framework;

Being clear and understandable.

The positive approach to teaching of teachers who are willing to deepen their professional knowledge and embrace challenges allows students to use teaching methods that enable them to think independently and critically about what they learn, taking into account different possibilities (Butler \& Shibaz, 2014). The methods and techniques used by the teacher in the course are the most effective factor in the students' acquisition of knowledge, skills and attitudes. Therefore, teachers who are the implementors of the learning-teaching process at school should have the qualifications required by 21 st century and the contemporary knowledge, skills and attitudes. In this direction, teachers should use the teaching methods and techniques that the student is at the center, which is defined as modern teaching methods at school. Because, in order to follow the developing and changing world, it is important for teachers to use contemporary teaching methods in their lessons rather than traditional methods.

Teachers should also be equipped with professional knowledge, skills, attitudes and values in order to prepare students for life. The aim of this present research is to reveal the relationship between physical education and sports teachers' teaching approaches and their teaching goal orientations.

It is considered to be significant for a quality education to determine the goals of physical education and sports teachers for the lesson. The teaching approaches of physical education and sports teachers are chosen and applied in line with the course objectives. The determination of the professional seniority relationship regarding the learning-teaching process of physical education and sports teachers, the determination of target orientations and teaching approaches towards teaching in lessons are important for a qualified physical education and sports lesson and will make significant contributions to the field.

The sub-goals for this research are as follows: 
- Teaching Approaches Inventory and Goal Orientation Scale for Teaching scales is there a difference according to seniority?

- Is there a relationship according to the Teaching Approaches Inventory sub-dimensions?

- Is there a relationship according to the Goal Orientation Scale for Teaching sub-dimensions?

- Is there a relationship between Instructional Approaches Inventory and Goal Orientation Scale?

\section{Method}

The "quantitative method" was used in this study, and the relational survey type was preferred as the research design.

\subsection{Participant}

A total of 279 physical education and sports teachers working at different schools in Elazig/Turkey participated in this study. The sample group was determined by simple random sampling. All participation was on a voluntary basis. In this study 279 participants, 242 were men and 33 were women. Of the 279 participants, 16 were 22-25 years old, 34 were 26-29 years old, 229 were over 30 years old. The reason for choosing this study group is that it is easily accessible by researchers.

\subsection{Data Collection Tools}

'Goal Orientation Scale for Teaching (15 items)' and 'Teaching Approaches Inventory (45 items)' were used to collect data. Information about the data collection tools is as follows:

Goal Orientation Scale for Teaching: This scale was firstly developed by (Butler, 2007) with 4 sub-dimensions (Yıldı, Saban, \& Baştuğ 2016). Adapted the scale that was developed by (Butler \& Shibaz, 2014) The reliability results of the sub-dimensions and the whole scale were determined between 0.605 and 0.787 .

Teaching Approaches Inventory: This scale was developed by (Pratt \& Collins, 2013) adapted to Turkish by (Tanrıverdi \& Geçer, 2015) For the reliability of the scale, the Cronbach Alpha internal consistency coefficient calculated and determined as 0.88 .

\subsection{Data Analysis}

After the data collection tools were applied to the participants, the data obtained were analyzed using a licensed SPSS 22.0 package program. First of all, it was examined whether the scales and their sub-dimensions provide the assumption of normality and it was determined that they display normal distribution. In order to determine the differentiation according to the professional seniority variable, One Way Analysis of Variance (ANOVA) used. Scheffe test was used to determine the variables among which the difference is. To determine the level and direction of the relationship between dependent variables 'Pearson Correlation Analysis' has been made. Statistical significance level ( $\alpha$ error level) was 
accepted as $\mathrm{p}<0.05$.

\subsection{Ethics Text}

The Ethics Committee Report of the study was received.

\section{Results}

In line with the aims of the study, the results obtained from the opinions of physical education and sports teachers are given below.

Table 1. One-way analysis of variance (ANOVA) results performed to determine whether the goal orientation scale for teaching and sub-dimensions show difference between the professional seniority variable of teachers

\begin{tabular}{|c|c|c|c|c|c|c|c|}
\hline Scale/Sub-Dimensions & Professional Seniority & $\mathrm{N}$ & $\overline{\mathbf{x}}$ & SD & $\mathrm{F}$ & $\mathrm{p}$-Value & Scheffe \\
\hline \multirow{5}{*}{$\begin{array}{l}\text { Goal Orientation } \\
\text { Scale for Teaching }\end{array}$} & (a) $0-5$ years & 31 & 3.574 & 0.597 & \multirow{5}{*}{18.486} & \multirow{5}{*}{0.000} & \multirow{5}{*}{$\begin{array}{l}\mathrm{a}<\mathrm{d} \\
\mathrm{b}<\mathrm{c} \\
\mathrm{b}<\mathrm{d} \\
\mathrm{b}<\mathrm{e}\end{array}$} \\
\hline & (b) 6-10 years & 55 & 3.295 & 0.511 & & & \\
\hline & (c) $11-15$ years & 74 & 3.591 & 0.530 & & & \\
\hline & (d) $16-20$ years & 83 & 4.014 & 0.444 & & & \\
\hline & (e) 20 years or more & 36 & 3.661 & 0.421 & & & \\
\hline \multirow{5}{*}{ Skill Approach } & (a) $0-5$ years & 31 & 3.451 & 0.949 & \multirow{5}{*}{9.095} & \multirow{5}{*}{0.000} & \multirow{5}{*}{$\begin{array}{l}\mathrm{a}<\mathrm{d} \\
\mathrm{b}<\mathrm{d} \\
\mathrm{b}<\mathrm{e} \\
\mathrm{c}<\mathrm{d}\end{array}$} \\
\hline & (b) 6-10 years & 55 & 3.309 & 0.931 & & & \\
\hline & (c) $11-15$ years & 74 & 3.496 & 0.847 & & & \\
\hline & (d) 16-20 years & 83 & 4.078 & 0.776 & & & \\
\hline & (e) 20 years or more & 36 & 3.888 & 0.811 & & & \\
\hline \multirow{5}{*}{ Mastery } & (a) $0-5$ years & 31 & 4.048 & 0791 & \multirow{5}{*}{11.078} & \multirow{5}{*}{0.000} & \multirow{5}{*}{$\begin{array}{l}\mathrm{b}<\mathrm{d} \\
\mathrm{c}<\mathrm{d}\end{array}$} \\
\hline & (b) 6-10 years & 55 & 3.700 & 0.798 & & & \\
\hline & (c) $11-15$ years & 74 & 4.010 & 0.640 & & & \\
\hline & (d) $16-20$ years & 83 & 4.433 & 0.481 & & & \\
\hline & (e) 20 years or more & 36 & 4.076 & 0.620 & & & \\
\hline \multirow{5}{*}{ Avoiding work } & (a) $0-5$ years & 31 & 2.935 & 1.123 & \multirow{5}{*}{5.424} & \multirow{5}{*}{0.000} & \multirow{5}{*}{$\begin{array}{l}\mathrm{b}<\mathrm{d} \\
\mathrm{d}>\mathrm{e}\end{array}$} \\
\hline & (b) 6-10 years & 55 & 2.590 & 1.053 & & & \\
\hline & (c) $11-15$ years & 74 & 2.952 & 0.881 & & & \\
\hline & (d) 16-20 years & 83 & 3.234 & 0.966 & & & \\
\hline & (e) 20 years or more & 36 & 2.513 & 0.821 & & & \\
\hline \multirow{5}{*}{ Student Relations } & (a) $0-5$ years & 31 & 3.957 & 0.909 & \multirow{5}{*}{9.221} & \multirow{5}{*}{0.000} & \multirow{5}{*}{$\begin{array}{l}\mathrm{b}<\mathrm{d} \\
\mathrm{b}<\mathrm{e} \\
\mathrm{c}<\mathrm{d}\end{array}$} \\
\hline & (b) 6-10 years & 55 & 3.678 & 0.813 & & & \\
\hline & (c) $11-15$ years & 74 & 4.013 & 0.696 & & & \\
\hline & (d) 16-20 years & 83 & 4,409 & 0.740 & & & \\
\hline & (e) 20 years or more & 36 & 4.333 & 0.632 & & & \\
\hline
\end{tabular}

Note. ${ }^{*} \mathrm{p}<0.05$. 
In the opinion of the participants, a significant difference was found in the professional seniority variable in the 'Goal Orientation Scale for Teaching' and sub-dimensions (Table 1). It was observed that the opinions of physical education and sports teachers, whose professional seniority was between 6-10 years, were at a lower level than those with other professional seniority.

Table 2. One-way analysis of variance (ANOVA) results performed to determine whether teaching approaches inventory and sub-dimensions show difference between the professional seniority of teachers

\begin{tabular}{|c|c|c|c|c|c|c|c|}
\hline Scale/Sub-Dimensions & Professional Seniority & $\mathrm{N}$ & $\overline{\mathbf{x}}$ & SD & $\mathrm{F}$ & $\mathrm{p}$-Value & Scheffe \\
\hline \multirow{5}{*}{$\begin{array}{l}\text { Teaching Approaches } \\
\text { Inventory }\end{array}$} & (a) $0-5$ years & 31 & 4.145 & 0.478 & \multirow{5}{*}{14.420} & \multirow{5}{*}{0.000} & \multirow{5}{*}{$\begin{array}{l}\mathrm{a}<\mathrm{d} \\
\mathrm{b}<\mathrm{d} \\
\mathrm{c}<\mathrm{d} \\
\mathrm{e}<\mathrm{d}\end{array}$} \\
\hline & (b) 6-10 years & 55 & 4.013 & 0.530 & & & \\
\hline & (c) $11-15$ years & 74 & 4.223 & 0.338 & & & \\
\hline & (d) 16-20 years & 83 & 4.517 & 0.363 & & & \\
\hline & (e) 20 years or more & 36 & 4.197 & 0.331 & & & \\
\hline \multirow{5}{*}{ Transfer } & (a) $0-5$ years & 31 & 4.129 & 0.525 & \multirow{5}{*}{6.216} & \multirow{5}{*}{0.000} & \multirow{5}{*}{$\begin{array}{l}\mathrm{a}<\mathrm{d} \\
\mathrm{b}<\mathrm{d} \\
\mathrm{d}>\mathrm{e}\end{array}$} \\
\hline & (b) $6-10$ years & 55 & 4.133 & 0.556 & & & \\
\hline & (c) $11-15$ years & 74 & 4.276 & 0.404 & & & \\
\hline & (d) $16-20$ years & 83 & 4.469 & -0.418 & & & \\
\hline & (e) 20 years or more & 36 & 4.185 & 0.414 & & & \\
\hline \multirow{5}{*}{ Apprenticeship } & (a) $0-5$ years & 31 & 4.197 & 0.546 & \multirow{5}{*}{12.820} & \multirow{5}{*}{0.000} & \multirow{5}{*}{$\begin{array}{l}\mathrm{a}<\mathrm{d} \\
\mathrm{b}<\mathrm{d} \\
\mathrm{c}<\mathrm{d} \\
\mathrm{e}<\mathrm{d}\end{array}$} \\
\hline & (b) 6-10 years & 55 & 4.133 & 0.538 & & & \\
\hline & (c) $11-15$ years & 74 & 4.196 & 0.446 & & & \\
\hline & (d) 16-20 years & 83 & 4.595 & 0.344 & & & \\
\hline & (e) 20 years or more & 36 & 4.228 & 0.377 & & & \\
\hline \multirow{5}{*}{ Developmental } & (a) $0-5$ years & 31 & 4.182 & 0.523 & \multirow{5}{*}{13.796} & \multirow{5}{*}{0.000} & \multirow{5}{*}{$\begin{array}{l}\mathrm{a}<\mathrm{d} \\
\mathrm{b}<\mathrm{d} \\
\mathrm{c}<\mathrm{d} \\
\mathrm{e}<\mathrm{d}\end{array}$} \\
\hline & (b) 6-10 years & 55 & 3.945 & 0.586 & & & \\
\hline & (c) $11-15$ years & 74 & 4.166 & 0.398 & & & \\
\hline & (d) 16-20 years & 83 & 4.512 & 0.434 & & & \\
\hline & (e) 20 years or more & 36 & 4.067 & 0.459 & & & \\
\hline \multirow{5}{*}{ Affective Supporter } & (a) $0-5$ years & 31 & 4.215 & 0.508 & \multirow{5}{*}{14.343} & \multirow{5}{*}{0.000} & \multirow{5}{*}{$\begin{array}{l}\mathrm{a}<\mathrm{d} \\
\mathrm{b}<\mathrm{d} \\
\mathrm{b}<\mathrm{e} \\
\mathrm{c}<\mathrm{d}\end{array}$} \\
\hline & (b) $6-10$ years & 55 & 4.002 & 0.535 & & & \\
\hline & (c) $11-15$ years & 74 & 4.231 & 0.368 & & & \\
\hline & (d) $16-20$ years & 83 & 4.548 & 0.406 & & & \\
\hline & (e) 20 years or more & 36 & 4.311 & 0.329 & & & \\
\hline
\end{tabular}




\begin{tabular}{|c|c|c|c|c|c|c|c|}
\hline \multirow{5}{*}{ Social Reform } & (a) $0-5$ years & 31 & 4.003 & 0.507 & \multirow{5}{*}{15.308} & \multirow{5}{*}{0.000} & \multirow{5}{*}{$\begin{array}{l}\mathrm{a}<\mathrm{d} \\
\mathrm{b}<\mathrm{c} \\
\mathrm{b}<\mathrm{d} \\
\mathrm{b}<\mathrm{e}\end{array}$} \\
\hline & (b) 6-10 years & 55 & 3.854 & 0.680 & & & \\
\hline & (c) $11-15$ years & 74 & 4.246 & 0.338 & & & \\
\hline & (d) $16-20$ years & 83 & 4.461 & 0.434 & & & \\
\hline & (e) 20 years or more & 36 & 4.194 & 0.350 & & & \\
\hline
\end{tabular}

Note. $* \mathrm{p}<0.05$.

As a result of the analysis, there was a significant difference in the professional seniority variable in the 'Teaching Approaches Inventory' and sub-dimensions (Table 2). Among the physical education and sports teachers, those with more professional seniority years generally stated a higher level of opinion on scale expressions.

Table 3. Correlation analysis results regarding the relationship between the teaching goal orientation scale and its sub-dimensions

\begin{tabular}{|c|c|c|c|c|c|c|}
\hline Scale/Sub Dimensions & Identifiers & 1 & 2 & 3 & 4 & 5 \\
\hline \multirow{3}{*}{$\begin{array}{l}\text { Goal Orientation Scale } \\
\text { for Teaching (1) }\end{array}$} & $\mathbf{r}$ & 1 & & & & \\
\hline & $\mathbf{p}$ & - & & & & \\
\hline & $\mathbf{N}$ & 279 & & & & \\
\hline \multirow{3}{*}{ Skill Approach (2) } & $\mathbf{r}$ & $0.789^{*}$ & 1 & & & \\
\hline & $\mathbf{p}$ & 0.000 & - & & & \\
\hline & $\mathbf{N}$ & 279 & 279 & & & \\
\hline \multirow{3}{*}{ Mastery (3) } & $\mathbf{r}$ & $0.576^{*}$ & $0.314^{*}$ & 1 & & \\
\hline & $\mathbf{p}$ & 0.000 & 0.000 & - & & \\
\hline & $\mathbf{N}$ & 279 & 279 & 279 & & \\
\hline \multirow{3}{*}{ Avoiding Work (4) } & $\mathbf{r}$ & $0.645^{*}$ & $0.421^{*}$ & 0.085 & 1 & \\
\hline & $\mathbf{p}$ & 0.000 & 0.000 & 0.158 & - & \\
\hline & $\mathbf{N}$ & 279 & 279 & 279 & 279 & \\
\hline \multirow{3}{*}{ Student Relations (5) } & $\mathbf{r}$ & $0.561^{*}$ & $0.182^{*}$ & $0.518^{*}$ & 0.051 & 1 \\
\hline & $\mathbf{p}$ & 0.000 & 0.002 & 0.000 & 0397 & - \\
\hline & $\mathbf{N}$ & 279 & 279 & 279 & 279 & 279 \\
\hline
\end{tabular}

Note. ${ }^{*} \mathrm{p}<0.05$. 
As a result of the correlation analysis (Table 3), it was determined that the relationship between 'Goal Orientation Scale for Teaching' and 'Skill Approach' sub-dimension ( $r=0.789$; $\mathrm{p}=0.000)$ was high and positive $(\mathrm{p}<0.05)$.

Table 4. Correlation analysis results regarding the relationship between teaching approaches inventory scale and sub-dimensions

\begin{tabular}{|c|c|c|c|c|c|c|c|}
\hline Scale Sub-Dimensions & Identifiers & 1 & 2 & 3 & 4 & 5 & 6 \\
\hline \multirow{3}{*}{ Teaching Approaches (1) } & $\mathbf{r}$ & 1 & & & & & \\
\hline & $\mathbf{p}$ & - & & & & & \\
\hline & $\mathbf{N}$ & 279 & & & & & \\
\hline \multirow{3}{*}{ Transfer (2) } & $\mathbf{r}$ & $0.865^{*}$ & 1 & & & & \\
\hline & p & 0.000 & - & & & & \\
\hline & $\mathbf{N}$ & 279 & 279 & & & & \\
\hline \multirow{3}{*}{ Apprenticeship (3) } & $\mathbf{r}$ & $0.906^{*}$ & $0.779^{*}$ & 1 & & & \\
\hline & $\mathbf{p}$ & 0.000 & 0.000 & - & & & \\
\hline & $\mathbf{N}$ & 279 & 279 & 279 & & & \\
\hline \multirow{3}{*}{ Developmental (4) } & $\mathbf{r}$ & $0.932^{*}$ & $0.733^{*}$ & $0.807^{*}$ & 1 & & \\
\hline & $\mathbf{p}$ & 0.000 & 0.000 & 0.000 & - & & \\
\hline & $\mathbf{N}$ & 279 & 279 & 279 & 279 & & \\
\hline \multirow{3}{*}{ Affective Supporter (5) } & $\mathbf{r}$ & $0.929^{*}$ & $0.740^{*}$ & $0.820^{*}$ & $0.848^{*}$ & 1 & \\
\hline & $\mathbf{p}$ & 0.000 & 0.000 & 0.000 & 0.000 & - & \\
\hline & $\mathbf{N}$ & 279 & 279 & 279 & 279 & 279 & \\
\hline \multirow{3}{*}{ Social Reform (6) } & $\mathbf{r}$ & $0.882^{*}$ & $0.668^{*}$ & $0.695^{*}$ & $0.809^{*}$ & $0.789^{*}$ & 1 \\
\hline & $\mathbf{p}$ & 0.000 & 0.000 & 0.000 & 0.000 & 0.000 & - \\
\hline & $\mathbf{N}$ & 279 & 279 & 279 & 279 & 279 & 279 \\
\hline
\end{tabular}

Note. $* \mathrm{p}<0.05$.

As a result of the correlation analysis (Table 4), the relationship between 'Teaching Approaches Inventory' and 'Developmental' sub-dimension $(r=0.932 ; p=0.000)$ was very high and positive $(\mathrm{p}<0.05)$. It was found that there is generally a high level and positive relationship between the scale and its sub-dimensions. 
Table 5. Correlation analysis results regarding the relationship between goal orientation scale towards teaching and teaching approaches inventory

\begin{tabular}{|l|l|l|l|}
\hline Scale & Identifiers & 1 & 2 \\
\hline \multirow{4}{*}{ Goal Orientation Scale for Teaching (1) } & $\mathbf{r}$ & 1 & \\
\cline { 2 - 5 } & $\mathbf{p}$ & - & \\
\cline { 2 - 5 } & $\mathbf{N}$ & 279 & \\
\hline \multirow{5}{*}{ Teaching Approaches Inventory (2) } & $\mathbf{r}$ & $0.616^{*}$ & 1 \\
\cline { 2 - 5 } & $\mathbf{p}$ & 0.000 & - \\
\cline { 2 - 5 } & $\mathbf{N}$ & 279 & 279 \\
\hline
\end{tabular}

Note. ${ }^{*} \mathrm{p}<0.05$.

As a result of the correlation analysis made according to the opinions of physical education and sports teachers, it was found that the relationship between goal orientations towards teaching and teaching approaches (Table 5) was moderate and positive $(r=0.616 ; p=0.000)$.

\section{Discussion}

Based on the opinion of the participants, in the 'Goal Orientation Scale for Teaching' and sub-dimensions significant differences were determined according to the professional seniority variable. It has been observed that the opinions of teachers between 6-10 years are lower than those with other professional seniority (Table 1). Saban and Yildizlı (2017) found that teachers with 1-5 years of professional seniority had a higher attitude towards goal orientation than teachers with 6-10 years of professional seniority. Teachers with 6-10 years of professional seniority were higher than teachers with 11-15 years of teaching experience. Skaalvik and Skaalvik (2013) emphasized that teachers' goal orientation is effective in their professional satisfaction. Üredi (2006) stated that the higher the teachers have professional seniority, the higher they have self-efficacy. Fasching et al. (2010) found that as teachers' teaching experience increased, their tendency to run away from work also increased. Saracaloğlu, Karasakaloğlu, and Evin-Gencel (2010) stated that teachers' use of teaching strategies and classroom management scores did not differ significantly according to their seniority in the profession. These studies show that as the professional seniority of physical education and sports teachers increase, the reason for their higher tendency towards expressions may be attributed to their being more experienced because they have more services in their profession. Because, the skills of physical education and sports teachers who have high professional experience, their willingness to work, their mastery and their better relations with students can be explained by their more experiences in their profession.

'Teaching Approaches Inventory Scale' and sub dimensions significant differences were determined according to the professional seniority variable. Among the teachers, those with more professional seniority generally stated higher scores for the items (Table 2). Other studies have also found a significant relationship between teachers' self-efficacy perceptions 
and professional seniority and teaching experiences (Cheung, 2008; Karahan, 2006; Köyalan, 2004; Maden, Durukan, \& Akbaş, 2011; Thompson, 2016) revealed that teachers with 6-10 years of professional seniority adopt a more student-centered teaching approach than teachers with 1-5 years of professional seniority. Cheung and Wong (2010) examined the curriculum orientations of teachers according to the seniority variable and they found that there was no significant difference in terms of seniority level in other sub-dimensions except the academic sub-dimension. Witcher et al. (2002) stated that unlike highly qualified teachers, teachers with low proficiency use more traditional methods in education, tend to apply rigid management strategies to create a controlled teaching environment in the classroom and to absenteeism from school. These studies show that it is a normal result that physical education and sports teachers with high professional seniority have more positive views on issues such as knowing the profession, learning and performing the duties required by the profession, internalizing professional ethics, transferring, apprenticeship, developmental, supportive and social reform.

As a result of correlation analysis, the highest relationship was found between 'Goal Orientation Scale for Teaching' and 'Skill Approach' (Table 3). Ha, Yin and Wang (2016) found an important relationship between teachers' goal orientation towards teaching and their loyalty to the profession. Schiefele and Schaffner (2015) concluded that teachers' mastery goal-oriented practices have a strong relationship with student motivation. Cho and Shim (2013) stated that in the school environment, some teachers have goal orientations such as focusing on improving their teaching skills, showing their teaching skills to others, and trying to hide the deficiencies in teaching skills. Demiröz and Yeşilyurt (2012) found that there was a positive relationship between skills orientation and working avoidance orientation. Nitsche et al. (2011) stated that teachers with mastery goal orientation have high perception of self-efficacy towards teaching, whereas teachers with performance goal orientation have low self-efficacy perception towards teaching. On the other hand, Butler (2007) claims that while teachers with skill approach goal orientation have a positive perception of seeking help, teachers with skill avoidance have a negative perception. Accordingly, physical education and sports teachers' skill approaches, mastery, avoidance of work and positive relations with students can be considered as the qualities that every teacher should have in their goal orientation towards teaching.

It was found that the relationship between the "Teaching Approaches Inventory' and 'Developmental' sub-dimension was positive and at a very high level. It has been determined that it is generally at a high level and positively among the scale and sub-dimensions (Table 4). In this respect Y. Feyzioğlu, E. Feyzioğlu, and Demirci (2016), emphasized that the environment in which they work affects teachers' teaching orientations. Ramnarain and Schuster (2014) stated that the teachers working in the rural mostly prefer the direct teaching approach in contrast to the teachers working in the urban. These studies show that many factors are important when presenting the teaching approaches of physical education and sports teachers. These factors can be listed as the teachers' experience and transfer in teaching, their applications in the teaching process, their developmental status at the learning stage, their support for students at all levels and social issues. 
It was determined that the relationship between physical education and sports teachers' goal orientation towards teaching and their teaching orientation was positive and at a medium level (Table 5). Dresel et al. (2013) stated that teachers' goal orientation is related to their activities in the teaching environment and they affect students' goal orientation. Üredi and Üredi (2009) concluded that teachers who have a student-centered teaching style have the highest score in preparing constructivist environments. Barrett, Bower, and Donovan (2007) stated that teachers who provide online education in public training centers in the United States mostly adopt teacher-centered teaching styles. Similarly, in some studies, significant relationships were found between teachers' teaching styles and student achievement (Davis, 2012; Karataş, 2004; Ling and Mann, 2010; Mendoza 2004). The relationship between the teaching goals of physical education and sports teachers and their teaching approaches is important when education is evaluated in a holistic framework. However, the absence of a high correlation in this study can be interpreted as it is related to the fact that physical education and sports lessons are mainly based on practices in addition to theoretical applications.

Similarly, many studies show that teachers' beliefs in education play an important role in shaping their teaching practices (Chan \& Elliott, 2004; Karakuş, 2006; Klein, 1977; Samuelowicz \& Bain, 2001). Pajares (1992) stated that teachers' beliefs and attitudes are an important factor that can affect their educational decision-making processes and their perceptions of a new situation.

\section{Conclusion}

The results of this study showed that the educational objectives, approaches and instructional behaviors of physical education and sports teachers in the education process are highly important. Teachers' enrichment of their teaching by establishing a relationship between their goal orientations and teaching approaches towards teaching physical education and sports lesson will further contribute to students' learning physical education and sports in a meaningful way. It will be beneficial for physical education and sports teachers to have in-service training at regular intervals in order to have good teaching skills, to gain new professional knowledge and skills, to develop more sincere and better relations with students, and to achieve the goals of their lessons. These responsibilities should be evaluated within the priorities of being a good and qualified teacher. It should not be forgotten that school administrators also have responsibilities in not avoiding the responsibilities of physical education and sports teachers with high professional seniority and in preparing them for the lessons in a planned and programmed manner. It is important for physical education and sports teachers to relate the subject matter to real life experiences. While physical education and sports teachers conduct the lessons theoretically and practically, they should not forget that students' learning is also linked to their past experiences. Teachers build on students' previously learned knowledge. Therefore, teachers should ensure that students develop in different and effective ways of reasoning. Thus, it is important to go beyond the usual methods while teaching a subject. Physical education and sports teachers should also be aware of the emotional reactions of students during the lesson process, provide students with self-confidence, and students should be rewarded for their efforts as well as their success in 
learning. In addition, the teacher should develop students' self-esteem, find something to appreciate in each student's response or contribution to the lesson, and encourage students to reveal their feelings and thoughts. Physical education and sports teachers should not forget that their teaching is focused on social change rather than the change of students. As a result of:

- Due to the scarcity of research on teaching goals and approaches of physical education and sports teachers, increasing both quantitative and qualitative research and evaluating them from different perspectives will contribute to the field.

- Putting forward the opinions of teachers on this subject with more research, revealing the problems they experience in education and training practices and their ideas about the innovations made in education programs will present a different perspective to the field.

\section{References}

Açıkgöz, K. Ü. (2003). Etkili öğrenme ve öğretme. İzmir: Education World Publications.

Anderman, E. M., Eccles, J. S., Yoon, K. S., Roeser, R., Wigfield, A., \& Blumenfeld, P. (2001). Learning to value mathematics and reading: Relations to mastery and performance-oriented instructional practices. Contemporary Educational Psychology, 26, 76-95. https://doi.org/10.1006/ceps.1999.1043

Aydede, M. N., Çağlayan, Ç., Matyar, F., \& Gülnaz, O. (2006). Fen ve teknoloji öğretmenlerinin kullandıkları öğretim yöntem ve tekniklerine ilişkin görüşlerinin değerlendirilmesi. Çukurova University Faculty of Education Journal, 3(32), 24-34.

Barrett, K. R., Bower, B. L., \& Donovan, N. C. (2007). Teaching styles of com-munity college instructors. American Journal of Distance Education, 21(1), 37-49. https://doi.org/ $10.1080 / 08923640701298738$

Butler, R. (2007). Teachers' achievement goal orientations and associations with teachers' help seeking: Examination of a novel approach to teacher motivation. Journal of Educational Psychology, 99(2), 241-252. https://doi.org/10.1037/0022-0663.99.2.241

Butler, R., \& Shibaz, L. (2008). Achievement goals for teaching as predictors of students' perceptions of instructional practices and students' help seeking and cheating. Learning and Instruction, 18(5), 453-467. https://doi.org/10.1016/j.learninstruc.2008.06.004

Butler, R., \& Shibaz, L. (2014). Striving to connect and striving to learn: influences of relational and mastery goals for teaching on teacher behaviors and student interest and help seeking. International Journal of Educational Research, 65, 41-53. https://doi.org/10.1016/ j.ijer.2013.09.006

Chan, K. W., \& Elliott, R. G. (2004). Relational analysis of personal epistemology and conceptions about teaching and learning. Teaching and Teacher Education, 20(8), 817-831. https://doi.org/10.1016/j.tate.2004.09.002 
Cheung, D., \& Wong, H. W. (2010). Measuring teacher beliefs about alternative curriculum designs. The Curriculum Journal, 13(2), 225-248. https://doi.org/10.1080/09585170210 136868

Cheung, Y. H. (2008). Teacher efficacy: A comparative study of hong kong and shanghai primary in-service teachers. The Australian Educational Researcher, 35(4), 103-123. https://doi.org/10.1007/BF03216877

Cho, Y. J., \& Shim, S. S. (2013). Predicting teachers' achievement goals for teaching: The role of perceived school goal structure and teachers' sense of efficacy. Teaching and Teacher Education, 32, 12-21. https://doi.org/10.1016/j.tate.2012.12.003

Davis, L. C. (2012). Exploring relationships among teaching styles, teachers 'perceptions of their self-efficacy and students' mathematics achievement (Ph.D. Dissertation, Liberty University, Virginia).

Demirel, Ö. (2012). Kuramdan uygulamaya ĕgitimde program geliştirme. Ankara: Pegema Publishing.

Demiröz, H., \& Yeşilyurt, S. (2012). Teaching motivation of ELT instructors through goal orientation perspective. e-International Journal of Educational Research, 3(2), 1-12.

Dresel, M., Fasching, M. S., Steuer, G., Nitsche, S., \& Dickhäuser, O. (2013). Relations between teachers' goal orientations, their instructional practices and students' motivation. Psychology, 4(7), 572-584. https://doi.org/10.4236/psych.2013.47083

Dursun, Ş., \& Dede, Y. (2004). The factors affecting students' success in mathematics: Mathematics teachers' perspectives. Gazi University Journal of Gazi Educational Faculty, 24(2), 217-230.

Dursun, Ş., \& Peker, M. (2003). Sixth grade students' primary school face-to-face problems in mathematics. Cumhuriyet University Journal of Social Sciences, 27(1), 135-142.

Fasching, M. S., Diel, M., Dickhäuser, O., \& Nitsche, S. (2010). Goal orientations of teacher trainees: Longitudinal analysis of magnitude, change and relevance. Journal For Educational Research Online, 2(2), 9-33.

Feyzioğlu, Y., Feyzioğlu, E., \& Demirci, N. (2016). Active direct or guided inquiry: examining the science teaching orientations of science teachers. Mehmet Akif Ersoy University Journal of Education Faculty, 39, 150-173.

Han, J., Yin, H., \& Wang, W. (2016). The effect of tertiary teachers' goal orientations for teaching on their commitment: The mediating role of teacher engagement. Educational Psychology, 36(3), 526-547. https://doi.org/10.1080/01443410.2015.1044943

Karahan, Ç. (2006). The observation of self-perceptions and job satisfactions of the secondary level elementary teachers (PhD Thesis, Institute of Social Sciences, Ege University, İzmir).

Karakuş, M. (2006). Öğretmen yetiştirmede felsefenin yeri ve önemi. Çukurova University 
Faculty of Education Journal, 1(31), 79-85.

Karataş, E. (2004). Bilgisayara giriş dersini veren ögretmenlerin ögretme stilleri ile dersi alan öğrencilerin ögrrenme stillerinin eşleştirilmesinin öğrenci başarısı üzerindeki etkisi (Master's Dissertation, Institute of Educational Sciences, Gazi University, Ankara).

Klein, D. S. R. (1977). Needed: Educational philosophy as a guide for decision-making in the public schools. Education, 97(3), 290-293.

Köyalan, A. (2004). Teaching efficacy and ability to manage classroom setbacks among instructors of English as a foreign languagage (Doctoral Thesis, Institute of Educational Sciences, Dokuz Eylül University, İzmir).

Kucsera, J. V., Roberts, R., Walls, S., Walker, J., \& Svinicki, M. (2011). Goal orientation towards teaching (GOTT) scale. Teachers and Teaching: Theory and Practice, 17(5), 597-610. https://doi.org/10.1080/13540602.2011.602212

Ling, L. M., \& Mann, C. P. (2010). Progressive versus traditional teaching styles-what really matters? Retrieved April 9, 2010, from http://www.ped.gu.se/biorn/phgraph/papers/lomun.pdf

Maden, S., Durukan, E., \& Akbaş, E. (2011). Primary school teachers' perceptions of student centered teaching. Mustafa Kemal University Journal of Social Sciences Institute, 8, 255-269.

Mendoza, S. (2004). Teaching styles of technological institutes faculty in El Salvador (Doctoral Dissertation, Capella University, Minnesota).

Nitsche, S., Dickhäuser, O., Fasching, M. S., \& Dselen, M. (2011). Rethinking teachers' goal orientations: Conceptual and methodological enhancements. Learning and Instruction, 21(4), 574-586. https://doi.org/10.1016/j.learninstruc.2010.12.001

Pajares, F. M. (1992). Teachers' beliefs and educational research: Cleaning up a messy construct. Review of Educational Research, 3, 307-332. https://doi.org/10.3102/0034654 3062003307

Pratt, D. D., \& Collins, J. B. (2013). Teaching perspectives inventory. Retrieved February 5, 2013, from http://www.edst.educ.ubc.ca/DPtpi.html

Ramnarain, U., \& Schuster, D. (2014). The pedagogical orientation of South African physical sciences teachers towards inquiry or direct instructional approaches. Research in Science Education, 44(4), 627-650. https://doi.org/10.1007/s11165-013-9395-5

Saban, A., \& Y1ldızl, H. (2017). Turkish primary school teachers' goal orientations for teaching. International Online Journal of Educational Sciences, 9(2), 348-355, https://doi.org/10.15345/iojes.2017.02.004

Samuelowicz, K., \& Bain, J. D. (2001). Revisiting academics' beliefs about teaching and learning. Higher Education, 41, 299-325. https://doi.org/10.1023/A: 1004130031247

Saracaloğlu, A. S., Karasakaloğlu, N., \& Evin-Gencel, İ. (2010). Analysis on turkish teachers' self-efficacy levels according to various variables. Electronic Journal of Social Sciences, 
9(33), 265-283.

Schiefele, U., \& Schaffner, E. (2015). Teacher interests, mastery goals, and self-efficacy as predictors of instructional practices and student motivation. Contemporary Educational Psychology, 42, 159-171. https://doi.org/10.1016/j.cedpsych.2015.06.005

Skaalvik, E. M., \& Skaalvik, S. (2013). Teachers' perceptions of the school goal structure: Relations with teachers' goal orientations, work engagement, and job satisfaction. International Journal of Educational Research, 62, 199-209. https://doi.org/10.1016/j.ijer. 2013.09.004

Tanrıverdi, B. Ö., \& Geçer, A. (2015). The adaptation of teaching perspectives inventory into Turkish. Journal of Educational Sciences, 6(2), 44-62.

Thompson, G. R. (2016). Japanese high school English teachers' self-efficacy beliefs about teaching English (PhD thesis, School of Cultural and Professional Learning, Faculty of Education, University of Technology, Queensland).

Üredi, I. T., \& Üredi, L. A. (2009). Variable which can be effective in constructivist learning environments: Teaching style preference. E-Journal of New World Sciences Academy, 4(4), 1171-1185.

Üredi, L. (2006). I. and II. level primary education teachers' perceptions about teaching profession according to their styles preference (Doctoral Thesis, Institute of Educational Sciences, Marmara University, Istanbul).

Witcher, L. A., Onwuegbuzie, A. J., Collins, K. M. T., Witcher, A. E., Minor, L. C., \& James, T. L. (2002). Relationship between teacher efficacy and beliefs about education among preservice teachers. The Annual Meeting of the Mid-South Educational Research Association 29th, November 6-8, 2002, Chattanooga, TN.

Yıldız, H., Saban, A., \& Baştuğ, M. (2016). Adaptation of goal orientations for teaching scale into Turkish. Elementary Education Online, 15(4), 1254-1267. https://doi.org/10.17051/ io. 2016.62664

\section{Copyright Disclaimer}

Copyright for this article is retained by the author(s), with first publication rights granted to the journal.

This is an open-access article distributed under the terms and conditions of the Creative Commons Attribution license (http://creativecommons.org/licenses/by/3.0/). 